\title{
Digital Crime on Account of Defamation of the President of the Republic of Indonesia
}

\author{
Muhamad Ali Fitran ${ }^{1}$, Faisal Santiago ${ }^{2}$ \\ \{alifitran@gmail.com ${ }^{1}$, faisalsantiago@borobudur.ac.id²\} \\ Universitas Borobudur, Jakarta, Indonesia ${ }^{1,2}$
}

\begin{abstract}
The motivation behind this review is to portray how the guideline of criminal slander in Indonesia's positive law and to depict Article 45 section (1) related to Article 27 passage (3) of the ITE Law against the instance of maligning of the President of Indonesia. This review utilizes a regularizing juridical methodology by investigating the laws and guidelines. The consequences of this examination, albeit criminally expressed in Article 27 section (3) of the ITE Law, in view of the great confidence of the culprits of cybercrime, slander of the president, the appointed authority turns into a go between to intervene clashes with the complainant. Notwithstanding, the Court's choice actually gives discipline to the culprits of this cybercrime.
\end{abstract}

Keywords: Crime; Cyber Crime; Defamation

\section{Introduction}

Alongside the quick advancement of society following the improvement of science and innovation, particularly data, it influences all parts of life. The aftereffect of humankind, from one viewpoint, brings issues to light of their freedoms. Then again with the dominance of cutting edge innovation makes individuals' lives more straightforward.[1] The criminal act of defamation directed in Law Number 19 of 2016 concerning Amendments to Law Number 11 of 2008 concerning Information and Electronic Transactions has trapped numerous casualties.

However, these developments also impact various forms of crime, both in quantity and quality. It is the duty of all of us to make law enforcement in Indonesia better.[2] The public's legal awareness is getting better while the laws that regulate it are no longer appropriate, causing the community not to obey it anymore.[3] As a result, an individual who violates a norm has a confident attitude towards the situation regulated by the standard. It is this particular attitude that makes him feel no need to obey the example.

According to Oemar Seno Adji[4], defamation is known as an insult. Many media and tools can carry out abuses on social media or defamation, one of which is using electronic media. The act of intentionally distributing information through electronic media that contain insults or defamation is regulated in Article 27 passage (3) of Law Number 19 of 2016 concerning Amendments to Law Number 11 of 2008 concerning Electronic Information and Transactions.

It ought to be understood that for this situation, the State, through the 1945 Constitution in Article 28E section (3), expresses that "everybody has the option to opportunity of affiliation, 
gathering, and articulation." The expression can have an importance; Each State ensures the opportunity of affiliation, affiliation, get together and opportunity of articulation, articulation of contemplations, suppositions, and perspectives as indicated by their heart. In-Law Number 39 of 1999 concerning Human Rights, Article 23 passage (2) expresses that "everybody is allowed to have, issue and scatter assessments as per his heart, orally or recorded as a hard copy through print media and electronic print media by considering the upsides of - strict qualities, profound quality, request, public interest, and the trustworthiness of the country."

Freedom of opinion, expression, and expression in public both orally and in writing and or through electronic media is often misunderstood. Space of view that is misused and misused has an impact on violating privacy rights, which in essence causes actions that harm others in the form of insults or defamation. This is a negative impact of technological developments, namely the existence of violations caused by misuse of technology by acts categorized as conventional criminal acts committed through electronic media that are part of cybercrime or cybercrime.

The State has controlled data and electronic exchanges through Law Number 19 of 2016 so that offering viewpoints through the web is held in this law. As already explained, freedom of expression is misunderstood as a part of cybercrime. So that the movement is always dynamic with differences and various types or forms of content. Therefore, modern society today is very dependent on life and daily activities with gadgets and the internet that can quickly provide information easily. So the extreme wing fanatics do not miss making a breakthrough in cyberspace to insult, demean, and bring down other people or "Cybercrime" whose target is to be informed to the broader community. This has proven to be very effective and fast, considering that all corners of Indonesia are now almost accessible with internet devices and various social media, which for 24 hours continuously provide news. These perpetrators use electronic devices as a means to commit crimes in cyberspace.

Crime is a form of deviant behavior that always exists and is inherent in every State of society.[5] Criminal acts will always exist, such as disease and death that continually repeat themselves. Criminal law, which is considered a tool or means for solving these problems, is expected to provide the right solution. Therefore, in the development of positive law and criminal law, it is necessary to improve and strive in a directed and integrated manner. For this reason, the codification and unification of specific legal fields and the preparation of new laws that are urgently needed will answer all the challenges due to the increase in crime and the development of criminal acts.[6]

It is necessary to have an article formulation regarding this form of crime through the politics of criminal law.[7] Legal politics is an activity to determine a choice regarding the goals and methods to achieve legal goals in society.[8] Legal politics as activities to choose values and apply values.[9] This means that the politics of criminal law is choosing values and using these values in reality to prevent delinquency and crime. Regarding this crime, it means that there is a combination of violations in cyberspace that impact the real world. That is the importance of the formulation of articles in the Information and Electronic Transactions Law regarding defamation.

Based on the brief description above, the author needs to research the law governing the crime of ITE against the corruption of defamation so that it is expected to provide knowledge for the Indonesian people on the implementation of the ITE Law against Cybercrime in the criminal act of defamation of the president.[10] 


\section{Methods}

The problem approach used in this paper is a normative juridical approach because it examines written law or positive law and includes systematics and legal material.[11] For this reason, research is needed, which is the main plan in the development of science. Normative legal analysis is obtained from literature studies because this research mainly focuses on secondary data in libraries.

Before the creator conducts research, first the exploration goals should be clear, then, at that point, search for the definition of the issue to be talked about, then, at that point, search for hypotheses and ideas, then, at that point, search and peruse and gather pertinent essential and auxiliary information after that are handled and laid out in this proposal, to get The information in this review were gathered through, to be specific, optional information, which are legitimate materials in the study taken from writing studies comprising of essential lawful materials, optional lawful materials, and non-lawful or tertiary materials.

To produce more rational research information and objective, the author, as an analytical instrument, will use the method of juridical-qualitative analysis, in the sense that was analyzing the data obtained by emphasizing the normative review of the object of research and the existing regulations as positive law.

\section{Discussion}

\subsection{Regulation of the Crime of Defamation of the President through Social Media in} Indonesian Positive Law

The term also commonly used for criminal acts against honor is the crime of "insult." From the point of view of the means or object of delict, which is the intent or purpose of the article, namely to protect "honor," then a crime against honor is more appropriate. But if viewed from the side of feit or deeds, the offense is not wrong. It means "integrity and good name are the rights of a person or human rights of every human being. Thus only humans can have the honor and a good reputation.

Article 310 and Article 311 of the Criminal Code threaten imprisonment and fines for someone who accuses another person of doing something. However, efforts to protect human dignity have not been realized in a meaningful way. Insults or defamation of someone is a legal provision that is most often used against the mass media. Slander that is spread in writing is known as libel, while verbal slander is the slider. Slander itself is usually a complaint offense, meaning that someone whose reputation has been defamed can file a lawsuit in a district court and indeed can get compensation. Imprisonment can also be applied to parties who commit defamation.

In the Criminal Code, criminal arrangements for criminal demonstrations of criticism are directed in Article 310 passage (1) of the Criminal Code, which states:

"Whoever purposefully assaults somebody's honor or notoriety by denouncing something, with the unmistakable goal of spreading the word about it for general society, is undermined with defamation with a most extreme fine of nine months or a greatest fine of 4,000500 rupiahs." 
In light of the article over, the scorn which can be rebuffed is completed by blaming somebody for having submitted a demonstration, with the aim that the allegation will be spread (known to many individuals), the supposed demonstration needn't bother with a show that is rebuffed like taking, stealing, infidelity, etc. This demonstration is a serious customary demonstration, which is dishonorable, for instance, claiming that somebody has sold himself. For this situation, it's anything but a demonstration that can be rebuffed, yet it is really humiliating for those concerned in case it is reported. The allegation should be made verbally. Assuming it is made recorded as a hard copy (letters) or pictures, the affront is called profanation or offending by letter (recorded as a hard copy) and can be likely to Article 310 section (2) of the Criminal Code.

In the Criminal Code, a person is considered to have defamed another person when that person intentionally and to make something known with the honor or good name of someone he knows. The Criminal Code depicts well slander, an objection offense, in particular as expressed in Article 310 section (1). A criminal occasion that is an affront is a demonstration of criticism that drops an individual's position, nobility, and great name by denouncing something, which means clear so it is known to the general population. This demonstration is deserving of a greatest detainment of nine months and a most extreme fine of 300 rupiahs. Some of the acts that are categorized as defamation are:

\section{a) Public Humiliation}

We are doing humiliation or other actions that degrade the dignity of others in public. Humiliation in public is considered an act that is not polite, violates decency, and destroys harmony. Therefore, these actions need to be penalized. The term in public does not always mean public but can include a house that many people attend.

\section{b) Humiliation in Front of One's Person}

Includes direct telephone pronunciation to the insulted person because there is practically no difference with face to face. Regarding insults with actions, so without saying a single word, there may be many different opinions, to what extent this act is an insult. It could be someone who laughs has offended people who feel laughed at.

The articles that constitute insults or defamation in the Criminal Code are:

1. Article 134, Article 136, Article 137 of the Criminal Code : "Offending the President and Vice President by communicating, appearing, posting in broad daylight is deserving of six years."

2. Article 142 of the Criminal Code: "Affronts submitted purposefully against the prevailing ruler or others from agreeable nations are deserving of a most extreme detainment of fifteen years or a greatest fine of 300 rupiahs."

3. Article 143 of the Criminal Code: "Deliberate affront to an individual addressing a far off country in Indonesia is deserving of a greatest detainment of five years or a most extreme fine of 300 rupiahs."

4. Article 144 paragraph (1) of the Criminal Code: "Whoever broadcasts, shows or sets up in open works containing abuses to the prevailing lord, or different heads of amicable nations, or individuals addressing outside nations in Indonesia, with the expectation that the offending substance is known to the general population, will be rebuffed by a greatest detainment of five years. nine months or a greatest fine of 300 rupiahs (2) If the liable 
party carries out the wrongdoing while at the same time doing his pursuit, and around then, two years have not passed since the sentence has become fixed, he might be disallowed from looking as a result of such a wrongdoing.

5. Article 207, Article 208, and Article 209 of the Criminal Code: Put-downs to the specialists and Public Business Entities are deserving of detainment of six years

6. Article 310, Article 311, Article 315, and Article 316 of the Criminal Code: Attacking/defaming someone's honor or reputation, being charged with writing, is punishable by imprisonment for nine months and sixteen months.

7. Article 317 paragraph (1) of the Criminal Code: "Whoever purposely presents a protest or bogus notice to the specialists, either recorded as a hard copy or recorded as a hard copy, about an individual so his honor or notoriety is assaulted, is undermined with an offensive grievance, with a greatest detainment of four years."

8. Article 320 and Article 321 of the Criminal Code: Affront or maligning of a dead individual is deserving of detainment for a long time.

In the interim, maligning brought out through online media is controlled in Article 27 passage (3) and Article 28 section (2) of Law Number 11 of 2008 concerning Information and Electronic Transactions as changed by Law Number 19 of 2016.

Article 27 section (3) of the ITE Law, specifically: "Each individual deliberately and without freedoms disseminates and sends and makes available Electronic Information that has annoying and disparaging substance."The elements in the article are:

1. One person

2. On purpose

3. Deeds: Distribute; Transmitting; and Make it accessible

4. Against the law, which is meant by "Without Rights."

5. The article is Electronic Information and electronic archives containing affronts and slander.

Meanwhile, Article 28 paragraph (2) of the ITE Law reads: "Each individual deliberately and without freedoms conveys data pointed toward causing sensations of scorn or antagonism towards specific people and local gatherings dependent on identity, religion, race, and between bunch (SARA)."

Criminal dangers for individuals who abuse Article 27 section (3) of the ITE Law are managed in Article 45 passage (3) of Law no. 11 of 2016, which peruses: "Each individual who purposefully and without freedoms conveys or communicates or makes open Electronic Information and Electronic Documents containing affronts and maligning as alluded to in Article 27 passage (3) will be rebuffed with detainment a limit of 4 (four) a long time and a greatest fine of Rp. 750,000,000.00 (700 and fifty million rupiah)."

Then, at that point, the criminal danger for individuals who abuse the arrangements of Article 28 passage (2) of the ITE Law is as directed in Article 45A section (2) of Law no. 19 of 2016, in particular: "Every individual who purposely and without freedoms scatters data pointed toward causing sensations of scorn and antagonism towards specific people and gatherings of individuals dependent on identity, religion, race, and between bunch (SARA) as alluded to in Article 28 section (2) will be rebuffed with detainment for a limit of 6 (six) a long time or a greatest fine of Rp. 1,000,000,000.00 (one billion rupiah).

We want to more deeply study the article above. Many gatherings imagine that Article 27 passage (3) of the ITE Law is a common offense. This arrangement is off-base, and we need to check out it from two things: the pith of the wrongdoing of affront and an authentic perspective. 
Fundamentally, slander is a demonstration of assaulting somebody's honor or notoriety with the goal that the individual's acceptable name is dirtied and harmed.

In deciding the presence of affronts or maligning, content and setting are fundamental parts. The defilement or harm to an individual's standing must be decided by the individual concerned. As it were, the casualty can emotionally contemplate what content or part of the Information or Electronic Document he feels has assaulted his honor or notoriety. Along these lines, lawful security is given to the person in question and not to others. Others can't pass judgment on as old as casualty's judgment.

Meanwhile, context plays a role in providing objective value to the content. Understanding the context includes a description of the mood of the victim and the perpetrator, the intent and purpose of the perpetrator in disseminating information, as well as the interests involved in publishing it. Therefore, expert opinion is needed to understand the context, such as linguists, psychologists, and communication experts.

Then, at that point, by and large, the arrangements of Article 27 passage (3) of the ITE Law allude to abuses or maligning managed in the Criminal Code (KUHP), particularly in Article 311 of the Criminal Code. In the Criminal Code, it is held that affront is an objection offense. Without a doubt, before the change to the ITE Law, there was no unequivocal arrangement that Article 27 passage (3) of the ITE Law establishes an objection offense. However, subsequent to changing to the ITE Law, the prerequisites for affront or criticism in Law no. 19 of 2016 is an objection offense. And surprisingly more unequivocally, this has been expressed by the Constitutional Court Decision Number 50/PUU-VI/2008. The choice is in regards to the assertion that Article 27 section (3) is an objection offense. With regards to the Constitutional Court point [3.17.1], which clarifies:

"That separated from the Court's contemplations as depicted in the past passage, the legitimacy and understanding of Article 27 section (3) of the ITE Law can't be isolated from the essential lawful standards in Article 310 and Article 311 of the Criminal Code as a variety delict which requires an objection (klacht) to can be arraigned, should likewise be treated against acts that are precluded in Article 27 passage (3) of the ITE Law, so that Article a quo should likewise be deciphered as an offense that requires a grievance (klacht) to be indicted under the steady gaze of the Court.

The article with respect to offending the president, the Draft Criminal Code (RKUHP), has been extended. In light of Article 264 of the draft RKUHP because of a gathering between the public authority and the DPR as of January 10, 2018, an individual who spreads affronts against the President or Vice President using data innovation can be condemned to detainment for a limit of five years.

Nonetheless, the dispersed substance can't be sorted as an affront in case it is done in the public interest, for truth and self-protection. This is underscored as a work to secure opportunity of articulation in a majority rule government.

In the mean time, in the old Criminal Code, put-downs to the President or Vice President through data innovation were not directed.

\subsection{Defamation Law Enforcement}

At the point when his honor or great name can assault an individual, it relies upon the subjectivity of the person in question, where he feels that his respectability feels polluted. In the mean time, as per the goal measure, it depends on an overall norm of general setting to decide that a demonstration is a demonstration of obliterating honor or great name or not. In the event that the appropriate response is positive, it tends to be utilized as motivation to 
characterize the go about as a demonstration of impiety. Here the qualities that live in the public eye become the action. Police, Prosecutors, and Judges should catch the significance of tolerability that lives locally.

The demonstration of assaulting somebody's honor or notoriety by blaming something for being done purposefully. The culprit needs the outcomes of his activities, acknowledgment, or great name assaults, specifically the other designated individual. What's more, the aim here should be coordinated to every one of the components behind it. Consideration is likewise focused on the part of "public information, " implying that in submitting a demonstration to assault somebody's honor or acceptable name, he understands that people in general can realize it by doing the activity.

Article 310 passage (2) directs composed profanation, in which the components comprise of; (a) all components in section (1); (b) blames for submitting a demonstration utilizing composing or pictures that are communicated, shown, or stuck; and (c) transparently. The importance of "transmission" is composing or pictures made in adequate numbers that can be printed or copied and afterward appropriated in any capacity. While the meaning of "shown" is to show composing or pictures whose content or which means is offending to the public so many individuals know about it. The significance of "appended" is composing or pictures joined to different items that can be stuck, like sheets, building dividers, etc.

In the act of insulting both verbally and in writing, the perpetrator is not punished if the action is carried out in the public interest or for self-defense. The meaning of the two words is not explained by normative juridical so that to evaluate it. It is left to the judge's judgment based on the case he is examining.

Second, criticize. As a rule, criticize is characterized as false words that are typically used to blame somebody. In Indonesian sentence structure, criticize is characterized as a word expected to attack individuals.[12] The arrangements in regards to criticize are directed in Article 311, which expresses that: 1) If he carries out a wrongdoing of oral maligning or composed slander, in case it is passable to demonstrate that what is asserted is valid, he doesn't demonstrate it, and the allegation is made in opposition to what is known, then, at that point, he is compromised for carrying out defame, with a greatest detainment of 4 years; and 2) The denial of the freedoms alluded to in Article 35 Number 13 might be forced. In light of the above arrangements, the components of Article 311 are (a) carrying out the wrongdoing of oral slander or composed maligning; (b) the presence of a license to demonstrate the reality of the charges; (c) can demonstrate reality; (d) claims are made; and (e) the charges are made in opposition to what is known.

From these components, it implies that an individual who perpetrates a wrongdoing of slander, both verbally and recorded as a hard copy, where on his allegation he is permitted to demonstrate it. He can't demonstrate it, while the charge he makes is in opposition to what he knows, that individual is said to have submitted criticize. In any case, it ought to be noticed that few out of every odd individual who perpetrates a wrongdoing of criticism can be permitted to demonstrate the reality of his allegation. Just criminal demonstrations of slander with explicit reasons can be allowed, while violations perpetrated for reasons other than that are not permitted to demonstrate the reality of the claims.

Authorization to demonstrate the reality of the allegation in the criminal demonstration of criticism might be allowed by the adjudicator if (a) the allegation is made in the public interest; (b) did justifiably, and (c) for the situation that the defamation is a government worker who is completing his obligations (Article 312). Proof in Article 312 isn't permitted if the thing affirmed must be indicted on an objection and the protest isn't recorded (Article 313). 
Another thing that is also considered is Article 314 of the Criminal Code, which relates to the criminal act of slander if the person who is thought to have been blamed by the judge for the show he has accused, in this case, cannot be imposed for slander. Article 314 reads 1) If those who are insulted by a judge's decision which becomes final are found guilty of the thing alleged, then the punishment for slander is impossible; 2) If the judge's decision becomes permanent acquitted of the thing accused, then the decision is seen as perfect evidence that the thing alleged is not true; and 3) If a criminal prosecution has been initiated against the person who was insulted, the prosecution for slander shall be discontinued until a final decision is obtained regarding the alleged matter.

Third, light abuses. The type of minor put-downs is contained in Article 315 of the Criminal Code, which peruses as follows: Every deliberate maltreatment that isn't disparaging or composed criticism carried out against an individual, either in open orally or recorded as a hard copy, or front of the individual himself, verbally or by deed. or then again by a letter sent or got to him, will be rebuffed for light disdain with a greatest detainment of four months and two weeks or a most extreme fine of 4,000 500 rupiahs.

As indicated by moral hypothesis, criminal law and the ethical aspect are two exceptionally close things. The criminalization of a demonstration can be founded on the virtues that live in the public eye. Corrupt demonstrations can be legitimized into law into a criminal demonstration. In the event that an underhanded deed isn't condemned, there will be strain among ethics and criminal law. This hypothesis can legitimize condemning criticism offenses in Indonesia following the way of life of the Indonesian individuals who actually maintain eastern culture.

Albeit the effect is more on irrelevant misfortunes, by implication, criticism can likewise affect material misfortunes to individuals who have specific positions, like financial specialists, specialists, or others that cause individuals' trust to diminish. For a specialist or finance manager, the decrease in individuals' trust in them can cause material misfortunes since it will influence pay. Since it brings about material misfortunes, maligning cases in numerous nations can likewise be settled utilizing common law instruments.

In view of the depiction over, the criminalization of maligning offenses is planned to ensure an individual's honor and acceptable name and urge somebody to treat others as indicated by their nobility as people. This assurance of honor and nobility is ensured in the 1945 Constitution, in particular Article 28 G Paragraphs (1) and (2), which peruses: (1) Everyone has the privilege to the insurance of himself, his family, honor, poise, and property under power, and has the option to a feeling of safety and security from the danger of dread to do or not accomplish something which is a common liberty; (2) Everyone has the option to be liberated from torment or treatment that corrupts human pride and has the option to acquire political refuge from another country.

In the mean time, the definition of maligning offenses can be seen from the criminal law hypothesis, both formal and material. In criminal law hypothesis, it is realized that the division of offenses depends on their definition, in particular legitimate offenses, material offenses, and formal-material offenses. Formal offenses will be offenses whose detailing just underlines their activities, without requiring any results, for instance, Article 362 of the Criminal Code concerning burglary. In the interim, it is known as a material offense if the subject of the detailing of an offense is the result, for instance, 355 Paragraph (2) of the Criminal Code concerning murder. Notwithstanding the two offenses, the definition of the offense can be as dress material, to be specific an offense whose detailing underlines the manner in which the demonstration was done and the outcomes, for instance, article 378 of the Criminal Code concerning extortion. 
As far as its detailing, maligning offenses directed in the Criminal Code and laws outside the Criminal Code are formal offenses that don't need any ramifications for the activities carried out. In this offense, an individual can be indicted if the criminal components have been satisfied without causing unavoidable impacts, for instance in Article 310 of the Criminal Code where an individual can be sentenced provided that it is demonstrated that he has purposefully assaulted somebody's honor or notoriety by denouncing something expected to be known to the general population. So there is no requirement for the results of these activities.

The proper plan of slander offenses is inclined to abuse, particularly by the experts for specific thought processes, in light of the fact that the models for acts containing criticism rely upon the abstract view of the individual being tended to. Consequently, it would be better if the articles were planned tangibly or officially. A material or formal definition can all the more likely satisfy one of the rules that should be clung to in criminal law, specifically nullum crimen, nulla poena sine lege certa (no wrongdoing without clear legal standards). Material or formal detailing can limit the event of misuse or deviation from the soul that is wanted by a law.

In the RKUHP, articles with respect to maligning offenses are kept up with; even pieces on abuses to the president and VP that the Constitutional Court has dropped are as yet raised. It's only that in the Draft Criminal Code, the article on affront is presently not as a proper offense yet material. The plan with material infractions can forestall demonstrations of maltreatment of force by the specialists in light of the fact that to utilize this article. It should be demonstrated that somebody's activities have caused inescapable results, for instance, as planned in the RKUHP, like creating problems or uproars in the public eye, brutality against individuals or products, breaking the solidarity and respectability of the country, or others.

The article on offending the president and VP is as yet considered to should be explicitly controlled in the impending Criminal Code in light of the fact that the president and VP are images of the State whose authority should be kept up with, particularly in eastern societies, for example, in Indonesia, a pioneer should be regarded more than others since convey a substantial order in securing the local area. Nonetheless, the detailing should be as a material offense with clear boundaries.

The formulation of defamation offenses in material offenses can be a middle ground of the controversy over criminalizing defamation offenses. First, the law will protect from insults, slander, and others committed by someone. The rule here does not only function as a deterrent because it is impossible to prevent this kind of action; therefore, it is necessary to have a legal umbrella containing sanctions as a medicine that can heal a reputation that has already been injured due to this act. Second, the law also provides space for freedom of expression and opinion so that society can continually develop and be the embodiment of democracy in this reform era.

To accommodate the spirit of freedom of the press, it is appropriate to make rules regarding defamation specifically for the press profession. UU no. 40 of 1999 concerning the Press (Law on the Press), which is currently in force, cannot be said to lex specialis against the provisions of the Criminal Code because the criminal clauses in it are only administrative crimes. Thus, although the Press Law regulates the existence of the right to answer the press against someone's objection to a news report, it still does not affect the criminal process.

The press can still be subject to articles on defamation offenses unless intended for the public interest. As regulated in Article 310 Paragraph (3) of the Criminal Code, this is not written defamation or defamation if the act is carried out in the public interest or because it is forced to defend oneself. The problem that arises then is related to the parameters of the public 
interest. The Criminal Code does not further explain the public interest, so the parameters are not clear. The clarity of the parameters of the public interest is essential, especially concerning the press, whose work is in the field of publication.

The occurrence of minor insults, besides being able to be carried out in public either orally or in writing, abuse can also be done in front of or in front of the person himself, either in words or actions. A person who curses another person by saying a whore, a whore, a prostitute, or by acts such as spitting in someone's face are acts that can be categorized as minor insults.

Fourth, criticize objections The criminal offense of defamation is controlled in Article 317 of the Criminal Code, which peruses: Whoever purposely presents a bogus protest or warning to the specialists, either recorded as a hard copy or recorded as a hard copy, about an individual so his honor or great name is assaulted, is compromised, for submitting an abusive question, with detainment a limit of four years. In view of the detailing of this article, the meaning of contamination or affront alludes to a similar importance in the Criminal Code. This is on the grounds that, as recently clarified, all arrangements in the Criminal Code, both as common principles of Book I and uncommon standards of Books II and III, are basically a solitary criminal framework so they become rules for criminal enactment outside the Criminal Code.

To trap the culprits with Article 27 passage (3) over, two things should be considered by cops so the presence of the article isn't utilized as a political instrument to stifle the inventiveness of the press world. To begin with, it is demonstrated that the emotional and objective components of Electronic Information and Electronic Documents have an aggregate substance of affronts and maligning. This implies that law implementation authorities don't really announce the culprit at fault for abusing Article 27 section (3) if the emotional component is demonstrated. In any case, they actually need to confirm whether Electronic Information and Electronic Documents containing abuses and slander disregard the qualities in Indonesia. Society or not.

The presence of specialists in the field of ITE, Language, and the Press is critical for law implementation authorities to present to survey whether a message or picture identified with specific Electronic Information and Electronic Documents circulated, communicated, or available has annoying and disparaging substance. Or then again not. In this way, it did not depend on the casualty's protest alone, not to mention the uneven understanding of cops. Up until now, not a couple of press individuals have been arraigned for criticism dependent on the proof of abstract components.

\section{Conclusion}

The existence of legal provisions regarding defamation on social media has a different legal basis. I am judging from the complaint offense or general offense. From this difference, there is a problem with the use of the legal basis. Based on the decision of the criminal case by the Panel of Judges, which decided the interlocutory decision, there was an error for the Investigator and the Public Prosecutor due to various considerations. With this decision, it does not mean that Defendant has not committed an act.

\section{References}


[1] L. H. C. Hulsman, "Critical criminology and the concept of crime," Criminol. Perspect. Essent. readings, pp. 311-316, 2013.

[2] F. Santiago, "Bunga Rampai Catatan Hukum," Perpust. Nas. RI. Katalog Dalam Terbit., 2016.

[3] E. Y. Kanter and S. R. Sianturi, Asas-asas hukum pidana di Indonesia dan penerapannya. Storia Grafika, 2002.

[4] O. S. Adji, Perkembangan delik pers di Indonesia. Erlangga, 1990.

[5] E. E. Supriyanto, M. Rachmawati, and F. J. Nugroho, "Transformative Policies and Infrastructure Strengthening Towards the Police Era 4 . 0,” J. Bina Praja, vol. 13, pp. 231-243, 2021.

[6] M. Hariyanto and A. Budianto, "Protection of Indigenous Peoples Law Based on the 1945 Constitution," 2021, doi: 10.4108/eai.6-3-2021.2306460.

[7] J. Snyder, "Reading Between the Lines: Statutory Silence and Congressional Intent Under the Antiterrorism Act," Br. J. Am. Leg. Stud., vol. 1, no. 1, 2012, [Online]. Available: https://www.bcu.ac.uk/cmsproxyimage?path=/_media/docs/bjals-issue1.pdf.

[8] M. Md, "Membangun Politik Hukum, Menegakkan Konstitusi," Pustaka LP3ES. Jakarta, 2006.

[9] J. Burke, "Law, politics and intelligence: a life of Robert Hope," J. Policing, Intell. Count. Terror., vol. 15, no. 2, pp. 187-188, 2020, doi: 10.1080/18335330.2020.1775278.

[10] H. Purnomo and A. Yosua, "Penegakan Hukum Terhadap Tindak Pidana Pencemaran Nama Baik Melalui Media Berdasarkan Konsep Hukum Pidana," Soumatera Law Rev., vol. 3, no. 2, pp. 54-67, 2020, [Online]. Available: http://repositorio.unan.edu.ni/2986/1/5624.pdf.

[11] B. A. Shaffer, "Graduate student library research skills: Is online instruction effective?," J. Libr. Inf. Serv. Distance Learn., vol. 5, no. 1-2, pp. 35-55, 2011, doi: 10.1080/1533290X.2011.570546.

[12] D. Guna, M. Salah, and S. Syarat, "Politik Hukum dalam Kitab Undang-Undang Hukum Pidana dalam Hukum Islam Terhadap Tindak Pidana Penistaan Agama," Usu Law J., vol. 6, no. 4, pp. 135-142, 2018. 